\title{
Demographic characteristics of 3 Artemisia tridentata Nutt. subspecies
}

\author{
BARRY L. PERRYMAN, AARON M. MAIER, ANN L. HILD, AND RICHARD A. OLSON
}

Authors are assistant professor, School of Veterinary Medicine, University of Nevada, Reno, Nev. Ph.D. Candidate, Department of Rangeland Ecosystem Science, Colorado State University, Ft. Collins, Colo. 80523; assistant professor and associate professor, Department of Renewable Resources, University of Wyoming, Laramie, Wyo. 82071. At the time of the research, A.M. Maier was a graduate research assistant at the University of Wyoming.

\begin{abstract}
Previous research suggested that woody plant recruitment may occur in pulses in semi-arid areas. The overall objective of this study was to determine if this pulse phenomena was recorded in the demographic structures of big sagebrush (Artemisia tridentata Nutt.) stands in Wyoming. In 1997, approximately 75 stem cross sections were collected from 9 stands of each of 3 subspecies of big sagebrush in Wyoming along elevation and climatic gradients. Annual growth-rings were used to identify year of establishment and demographic characteristics were analyzed from ageclass frequencies. Mean stand ages of the 3 subspecies were different $(\mathbf{P}=\mathbf{0 . 0 0 2})$, and analyses revealed that Wyoming $(A$. tridentata ssp. wyomingensis) and mountain big sagebrush (A. tridentata ssp. vaseyana) stand ages (32 \pm 9 and $26 \pm 9$ years, respectively) were significantly older than basin big sagebrush (A. tridentata ssp. tridentata $)(17 \pm 3)$ stands $(\mathrm{P}<0.05)$. Mean recruitment intervals (years) were shorter for basin (1.6) than for Wyoming (2.3) and mountain (2.2) sagebrush $(P=0.01)$. The number of cohorts did not differ among the subspecies $(P=0.11)$, but the percent of years with recruitment was significantly higher for basin (59\%) compared to Wyoming (37\%) and mountain (39\%) subspecies $(\mathbf{P}<\mathbf{0 . 0 0 0 1})$. Age-class frequency distributions of each stand and regional stand combination were assessed for dispersion across each associated period of record. Chi-square goodness-of-fit tests were performed for the negative binomial distribution. All stands (with one exception) and all 3 regional stand combinations fit the negative binomial distribution. Ageclass frequency patterns indicate that recruitment is clustered or aggregated across each period of record. Recruitment in big sagebrush stands occurs in pulses throughout Wyoming.
\end{abstract}

Key Words: demography, big sagebrush, recruitment intervals

All 3 subspecies of big sagebrush, basin (Artemisia tridentata Nutt. ssp. tridentata), mountain (A. tridentata ssp. vaseyana [Rydb.] Beetle), and Wyoming (A. tridentata ssp. wyomingensis Beetle and Young) characterize many rangeland communities, occupying about $150,800 \mathrm{~km}^{2}$ of rangelands in Wyoming (Beetle and Johnson 1982). Big sagebrush has a wide ecological ampli-

Research was funded by the Wyoming Abandoned Coal Mined-Lands Research Program at the University of Wyoming. This support was administered by the Wyoming Department of Environmental Quality from funds returned to Wyoming from the Office of Surface Mining of the U.S. Department of the Interior.

Manuscript accepted 13 Jun. 2000.

\section{Resumen}

Investigación previa sugiere que en áreas aridas y semiáridos el establecimiento poblaciones de plantas leñosas puede ocurrir en pulsos. El objetivo general de este estudio fue determinar si este fenómeno de pulsos se registro en la estructura demográfica de poblaciones de "Big sagebrush" (Artemisa tridentata Nutt.) situadas en Wyoming. En 1997 se colectaron aproximadamente 75 secciones transversales de tallos de 9 poblaciones de cada una de las 3 subespecies de "Big sagebrush" presentes en Wyoming, la colecta se realizó a lo largo de gradientes climáticos y de elevación. Se utilizaron los anillos de crecimiento anual para identificar el año de establecimiento y las características demográficas se analizaron mediante frecuencias de edad-clase. La edad media de las 3 subespecies fue diferente $(P=0.002)$ y los análisis revelaron que las edades de las poblaciones de las subespecies "Wyoming" (A. tridentata ssp. wyomingenesis) y "Mountain big sagebrush" (A. tridentata ssp. vaseyana) $(32 \pm 9$ y $26 \pm 9$ años, respectivamente) fueron significativamente mayores que la edad de las poblaciones de la subespecie "Basin big sagebrush" $(A$. tridentata ssp. tridentata $)(17 \pm 3)(P<0.05)$. Los intervalos de establecimiento (años) fueron mas cortos para la subespecie "Basin big sagebrush" (1.6) que los de las subespecies "Wyoming" (2.3) y "Mountain big sagebrush" (2.2) $(\mathrm{P}=0.01)$. El numero de generaciones no difirió entre subespecies $(P=0.11)$, pero el porcentaje de años con establecimiento de plantas fue significativamente mayor para la subespecie "Basin big sagebrush" (59\%) que el de las subespecies "Wyoming"(37\% y "Mountain big sagebrush" $(39 \%)(P=\mathbf{0 . 0 0 0 1})$. Las distribuciones de frecuencia de edad-clase de cada población y la combinación regional de poblaciones se evaluó para ver la dispersión a través de cada periodo asociado con el registro. Se efectuaron pruebas de bondad de Chi-cuadrada para la distribución binomial negativa. Todas las poblaciones (excepto una) y todas las 3 combinaciones regionales de poblaciones tuvieron un distribución binomial negativa. Los patrones de frecuencia edad-clase indican que el establecimiento es aglomerado o agregado a través de cada periodo de registro. El establecimiento de poblaciones de "Big sagebrush" ocume en pulsos a través de Wyoming.

tude and occupies a diversity of habitats (Beetle 1960), playing crucial roles in reducing erosion, providing wildlife habitat, and improving rangeland aesthetics (Vale 1974).

Distribution is related to elevation, temperature, and soil moisture (Cawker 1980). Wyoming sagebrush occurs at low to mid elevations on fine-textured soils; Basin sagebrush at low to mid elevations but on deep, well-developed soils; and mountain 
sagebrush from mid to high elevations where cooler temperatures, higher precipitation, and developed soils are prevalent (Beetle 1960).

Pulses of recruitment in desert plant communities was suggested by Went (1955) and demonstrated for creosote bush (Larrea tridentata [DC.] Cov.) (Chew and Chew 1965, Barbour 1969), for threetip sagebrush (Artemisia tripartita Rydb.) and granite pricklygilia (Leptodactylon pungens [Torr.] Nutt.) (West et al. 1979). Unusual climatic events and high soil moisture conditions are suggested as major contributing factors (Noy-Meir 1973, Cawker 1980). A pulse is an infrequent recruitment of many individuals into a population. Cawker (1980) demonstrated evidence of climatic control of big sagebrush survival in British Columbia. If rare or infrequent climatic events control pulses of big sagebrush recruitment, these events should be evident within stand age structures as variations in age class frequency. Demography patterns of big sagebrush in Wyoming have not been assessed. Concerns about wildlife species obligate to big sagebrush and declining habitat quantity/quality require a comprehensive understanding of big sagebrush ecology.

This project was conducted to examine the age structure of 9 stands of each of the 3 subspecies on 27 native sites within 3 geographic areas of Wyoming. Specific objectives were to: 1) determine individual and stand ages; 2) compare stand ages, periods of record, number of cohorts, percent of years with recruitment, and recruitment intervals between subspecies; and 3) assess the dispersion of age-class frequencies through time.

\section{Materials and Methods}

Mature big sagebrush stands having similar soil characteristics and topography, and minimal herbivory disturbance were selected for this study. Sites were selected to minimize microsite effects that increase or decrease supplemental moisture conditions, thereby minimizing potential variations in recruitment and survival rates between sites (Roughton 1972, Bonham et al. 1991).

Stem sections for wyomingensis were collected from 3 stands in northeast Wyoming near Rochelle; 3 stands in the South Fork of the Powder River watershed, northwest of Casper in central Wyoming; and 3 stands in southwest Wyoming near Pinedale. Stem sections for tridentata were collected from 3 stands near Pinedale; 3 stands near Worland, on the west slope of the Bighorn Mountains; and 3 stands near Farson, in southwest Wyoming. Stem sections for vaseyana were collected from 3 stands near Pinedale; 3 stands near Buffalo, on the east slope of the Bighorn Mountains; and 3 stands west of Laramie, near Elk Mountain in south central Wyoming. The 3 stands in each regional grouping were located within a 15 mile radius. All stand coordinates were determined with a Global Positioning System, and are published in Perryman and Olson (2000).

A stratified, random sampling method was used to collect stem cross-sections from each stand. A permanent 100-m baseline transect was located within each stand, and ten, 100-m perpendicular transects were established at randomly selected points along the baseline transect. Along each perpendicular transect, 8 random points were selected, and the closest indi-

Table 1. Mean and median stand and regional stand combination ages (years) by subspecies, 1997.

\begin{tabular}{|c|c|c|c|}
\hline$\underline{\text { Subspecies, Stand, and Regional Combination }}$ & Mean & Median & $\mathrm{n}$ \\
\hline $\begin{array}{l}\text { wyomingensis } \\
\text { Stand Rochelle1 } \\
\text { Stand Rochelle2 } \\
\text { Stand Rochelle3 } \\
\text { Northeast WY (Rochell1,2,3 combined) } \\
\text { Stand TT Ranch1 } \\
\text { Stand TT Ranch2 } \\
\text { Stand TT Ranch3 } \\
\text { Southwest WY (TTRanch1,2,3 combined) } \\
\text { Stand Midwest1 } \\
\text { Stand Midwest2 } \\
\text { Stand Midwest3 } \\
\text { Central WY (Midwest1,2,3 combined) }\end{array}$ & $\begin{array}{l}28 \\
23 \\
26 \\
26 \\
32 \\
30 \\
21 \\
27 \\
45 \\
50 \\
39 \\
45\end{array}$ & $\begin{array}{l}25 \\
19 \\
28 \\
25 \\
33 \\
29 \\
16 \\
29 \\
46 \\
50 \\
39 \\
46\end{array}$ & $\begin{array}{r}78 \\
73 \\
73 \\
224 \\
61 \\
58 \\
59 \\
178 \\
69 \\
65 \\
67 \\
201\end{array}$ \\
\hline $\begin{array}{l}\text { vaseyana } \\
\text { Stand Elk Mountain1 } \\
\text { Stand Elk Mountain2 } \\
\text { Stand Elk Mountain3 } \\
\text { Southcentral WY (Elk Mountain1,2,3 combined) } \\
\text { Stand East Slope1 } \\
\text { Stand East Slope2 } \\
\text { Stand East Slope3 } \\
\text { Central WY (East Slope1,2,3, combined) } \\
\text { Stand Pinedale1 } \\
\text { Stand Pinedale2 } \\
\text { Stand Pinedale3 } \\
\text { Southwest WY (Pinedale1,2,3 combined) }\end{array}$ & $\begin{array}{l}19 \\
21 \\
26 \\
22 \\
23 \\
15 \\
17 \\
18 \\
44 \\
34 \\
31 \\
36\end{array}$ & $\begin{array}{l}19 \\
17 \\
18 \\
18 \\
19 \\
16 \\
17 \\
17 \\
47 \\
35 \\
25 \\
35\end{array}$ & $\begin{array}{r}67 \\
69 \\
69 \\
205 \\
67 \\
81 \\
76 \\
224 \\
60 \\
57 \\
67 \\
184\end{array}$ \\
\hline $\begin{array}{l}\text { tridentata } \\
\text { Stand West Slope1 } \\
\text { Stand West Slope2 } \\
\text { Stand West Slope3 } \\
\text { Central WY (West Slope1,2,3 combined) } \\
\text { Stand Big Sandy1 } \\
\text { Stand Big Sandy2 } \\
\text { Stand Big Sandy3 } \\
\text { Southwest WY1 (Big Sandy1,2,3 combined) } \\
\text { Stand Big Piney1 } \\
\text { Stand Big Piney2 } \\
\text { Stand Big Piney3 } \\
\text { Southwest WY }{ }^{2} \text { (Big Piney1,2,3 combined) } \\
\end{array}$ & $\begin{array}{l}22 \\
22 \\
14 \\
19 \\
20 \\
15 \\
14 \\
17 \\
14 \\
17 \\
16 \\
16 \\
\end{array}$ & $\begin{array}{l}21 \\
21 \\
13 \\
21 \\
20 \\
14 \\
12 \\
14 \\
13 \\
17 \\
16 \\
16 \\
\end{array}$ & $\begin{array}{r}76 \\
70 \\
78 \\
224 \\
70 \\
73 \\
68 \\
211 \\
74 \\
76 \\
72 \\
222 \\
\end{array}$ \\
\hline
\end{tabular}

${ }^{\mathrm{T}}$ West slope of the Green River Basin

${ }^{2}$ East slope of the Green River Basin the closest individual was not suitable for accurate age determination (e.g., damaged stem), another random point was selected until a suitable individual was found.

Stem cross-sections were obtained by sawing the plant below ground level (Ferguson 1964) to ensure that the pith and first annual growth ring were included. The stem was then cut approximately $10 \mathrm{~cm}$ above the first cut, yielding a $10 \mathrm{~cm}$ long stem section. Sampling was conducted during the summer of 1997. Between 75 and 80 stem sections were collected from each stand (Cawker 1980).

In the laboratory, the bottom portion of each stem section was sanded sequentially with $60,80,320$, and 400 grit sanding belts. Annual growth-rings were examined using a 10 power stereo microscope, and enumerated once by 2 different technicians for a total of 2 observations per sample. vidual big sagebrush plant was sampled. If 
Annual growth-rings are formed when the secondary xylem forms concentric rings around the stem during the growing season. Rings are easily distinguished from one another by a distinct cork layer 8-18 cells wide (Ferguson 1964). This layer is produced throughout the growing season between the old and new xylem.

Inter-annual or false rings have not been encountered in big sagebrush at northern latitudes and higher elevations (Diettert 1938, Moss 1940, Ferguson 1964, Perryman and Olson 2000). Location and elevation of sites in Wyoming fulfill both of these criteria. Locally absent rings do occur, however complete absence of rings is almost never encountered due to the unique nature of annual growth-ring formation in big sagebrush (Ferguson 1964, Perryman and Olson 2000).

Many older stems are "lobed" or "rosette" in form and lack radial symmetry. Often the decumbent and decadent form of older stems leads to open pith exposure and deterioration. Accurate age assessments are not possible when the pith is absent. Our sampling was biased for single-stemmed plants with intact piths over individuals without radial symmetry. As a result, some older plants with decadent stems were excluded.

Mean recruitment intervals, periods of record, number of cohorts, and percent of years with recruitment were determined for each subspecies on a statewide scale and assessed with one-way analysis of variance. Multiple comparisons of means were performed using the least significant difference (LSD) test (Saville 1990). Ageclass frequency distributions were constructed for each subspecies at 2 geographic scales, stand and regional stand combination. Age-class frequency dispersion through time was assessed by Chisquare goodness-of-fit tests for both Poisson (random) and negative binomial (clustered/aggregated) distributions (Ludwig and Reynolds 1988, Zar 1999). All analyses were determined significant at $\mathrm{P}<0.05$.

\section{Results and Discussion}

Individual plants and stands were generally younger than those found in previous big sagebrush dendrochronologic studies (Ferguson 1964, Roughton 1972, Cawker 1980). Prior research indicated that big sagebrush plant age often exceeds 100 years (Blaisdell 1953, Ferguson 1964) in the southwestern U.S. The oldest individual (81 years) in this study was a mountain
Table 2. Mean recruitment intervals (years), mean number of cohorts in the period of record, mean percent of recruitment years in the period of record, and mean period of record (years) by subspecies sampled across 27 sites in Wyoming, 1997.

\begin{tabular}{lcccc}
\hline \hline Subspecies & \multicolumn{1}{c}{ Interval $^{1}$} & Cohorts & Recruitment Years & Period of Record \\
\hline & $($ YR $)$ & $($ No. $)$ & $(\%)$ & $($ YR $)$ \\
wyomingensis & $2.3^{\mathrm{a}}( \pm 0.7)$ & $23^{\mathrm{a}}( \pm 1.9)$ & $37^{\mathrm{a}}( \pm 5)$ & $62( \pm 6)$ \\
vaseyana & $2.2^{\mathrm{a}}( \pm 0.7)$ & $21^{\mathrm{a}}( \pm 4.1)$ & $39^{\mathrm{a}}( \pm 6)$ & $54( \pm 14)$ \\
tridentata & $1.6^{\mathrm{b}}( \pm 0.6)$ & $20^{\mathrm{a}}( \pm 2.4)$ & $59^{\mathrm{b}}( \pm 9)$ & $34( \pm 8)$ \\
\hline
\end{tabular}

${ }^{1}$ Means with the same superscript within a column are not significantly different (P>0.05, LSD). sagebrush plant located in the Bighorn Mountains. The oldest Wyoming sagebrush plant ( 75 years) was from the Powder River Basin, and the oldest basin sagebrush plant (55 years) was found near Pinedale, Wyo. Young seedlings, 5-10 years old, were common in all stands.
Sampling bias for plants with intact piths may have potentially lowered mean stand ages, however, both younger and older plants were excluded when they lacked intact piths.

Analysis of variance indicated that mean stand ages of the 3 subspecies were differ-
Table 3. Results of Chi-square goodness-of-fit tests for the negative binomial (p-value and k-exponent value) distribution of individual stands and regional stand combinations, across Wyoming,1997. (Poisson distribution tests were all significant at $\mathbf{P}<0.0001$ ).

\begin{tabular}{|c|c|c|}
\hline Stand, and Regional Combination & P-value & $\mathrm{k}$ \\
\hline \multicolumn{3}{|l|}{ wyomingensis } \\
\hline Rochelle1 & 0.22 & 0.2387 \\
\hline Rochelle2 & 0.83 & 0.2119 \\
\hline Rochelle3 & 0.64 & 0.2145 \\
\hline Northeast WY (Rochelle 1,2,3 combined) & 0.50 & 0.2236 \\
\hline TT Ranch1 & 0.19 & 0.3612 \\
\hline TT Ranch2 & 0.23 & 0.5818 \\
\hline TT Ranch3 & 0.44 & 0.3962 \\
\hline Southwest WY (TT Ranch 1,2,3 combined) & 0.35 & 0.5377 \\
\hline Midwest1 & 0.75 & 0.2499 \\
\hline Midwest2 & 0.32 & 0.3043 \\
\hline Midwest3 & 0.56 & 0.3218 \\
\hline Central WY (Midwest 1,2,3 combined) & 0.71 & 0.3667 \\
\hline \multicolumn{3}{|l|}{ vaseyana } \\
\hline Elk Mountain 1 & 0.56 & 0.4662 \\
\hline Elk Mountain2 & 0.99 & 0.3052 \\
\hline Elk Mountain3 & 0.32 & 0.2348 \\
\hline Southcentral WY (Elk Mtn. 1,2,3 combined) & 0.67 & 0.2674 \\
\hline East Slope1 & 0.23 & 0.3029 \\
\hline East Slope2 & 0.59 & 0.1538 \\
\hline East Slope3 & 0.84 & 0.2509 \\
\hline Central WY (East Slope 1,2,3 combined) & 0.45 & 0.1659 \\
\hline Pinedale1 & 0.91 & 0.2337 \\
\hline Pinedale2 & 0.81 & 0.3322 \\
\hline Pinedale3 & $0.009 *$ & 0.3480 \\
\hline Southwest WY (Pinedale 1,2,3 combined) & 0.34 & 0.3698 \\
\hline \multicolumn{3}{|l|}{ tridentata } \\
\hline West Slope1 & 0.31 & 0.4497 \\
\hline West Slope2 & 0.51 & 0.4889 \\
\hline West Slope3 & 0.54 & 0.4069 \\
\hline Central WY (West Slope 1,2,3 combined) & 0.11 & 0.4111 \\
\hline Big Sandy1 & 0.14 & 1.2299 \\
\hline Big Sandy2 & 0.76 & 0.3408 \\
\hline Big Sandy 3 & 0.68 & 0.6599 \\
\hline Southwest WY ${ }^{1}$ (Big Sandy 1,2,3 combined) & 0.31 & 0.6838 \\
\hline Big Piney1 & 0.40 & 0.6382 \\
\hline Big Piney2 & 0.69 & 0.4016 \\
\hline Big Piney3 & 0.79 & 0.2247 \\
\hline Southwest WY ${ }^{2}$ (Big Piney 1,2,3 combined) & 0.87 & 0.2403 \\
\hline
\end{tabular}

${ }^{1}$ West slope of the Green River Basin

${ }^{2}$ East slope of the Green River Basin

*Only stand or stand combination that did not fit the negative binomial distribution. 

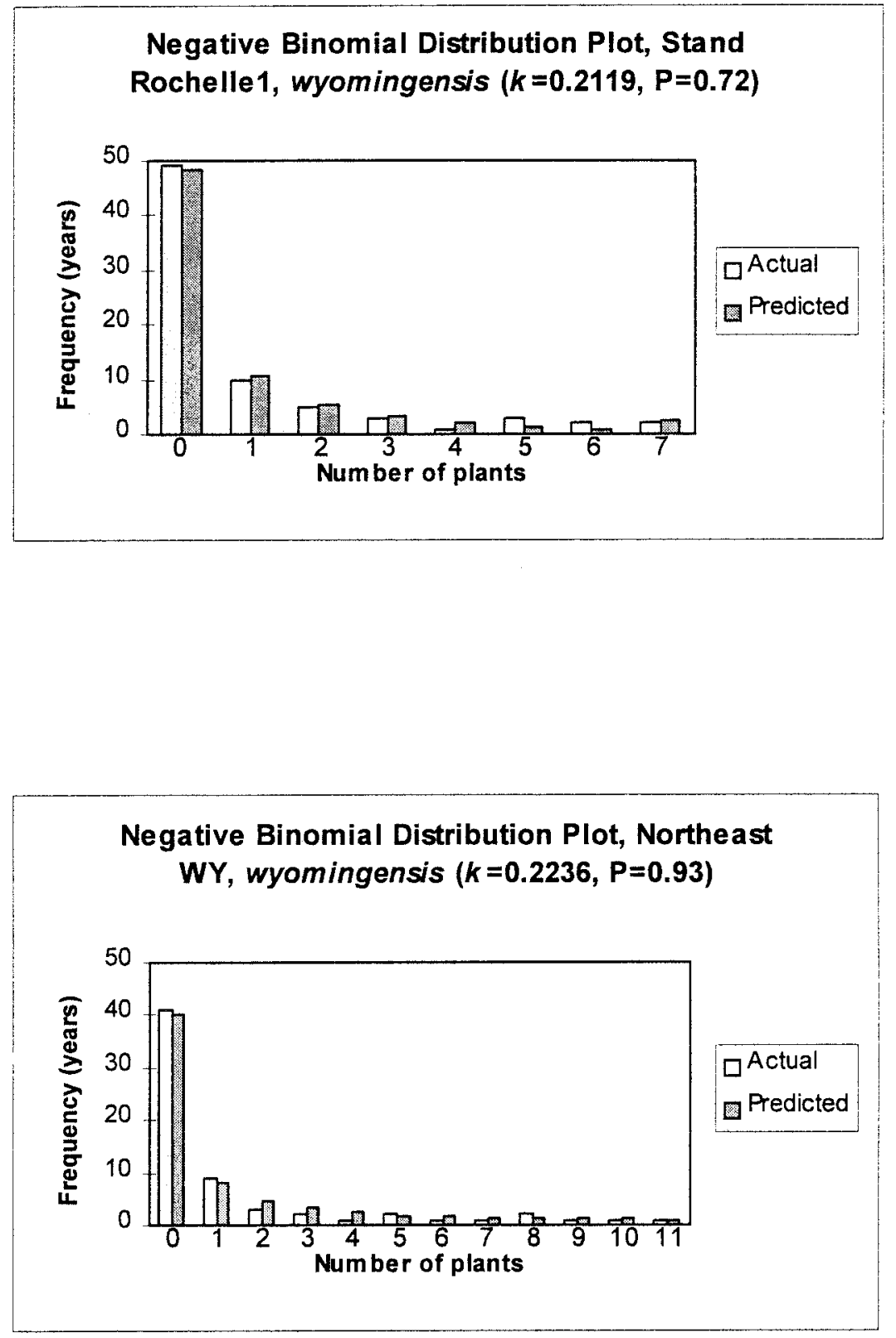

Fig. 1. Negative binomial distribution plots from Chi-square goodness-of-fit tests of (a) a representative stand and (b) a regional combination of stands for Wyoming sagebrush, sampled in northeast Wyoming, 1997.

ent, and the LSD test revealed that Wyoming and mountain sagebrush stands $(32, \pm 9$ and $26, \pm 9$ years respectively) were older than basin sagebrush $(17, \pm 3)$ stands. Mean and median ages for stands and geographic stand combinations by subspecies are listed in Table 1. No difference in stand ages occurred among geographic region $(\mathrm{P}=0.60)$.

Mean recruitment intervals, period of record, number of cohorts, and percent of years with recruitment are in Table 2 . Stand recruitment intervals ranged from 1.9 to 2.7 years for Wyoming sagebrush; recruitment conditions and higher rates of seedling survival. Less favorable climatic conditions may lengthen intervals in regions where Wyoming and mountain sagebrush plants occur (West 1978, Cawker 1980).

The number of cohorts did not differ among subspecies, but the percent of successful recruitment years was significantly higher for basin sagebrush (59\%) than for the Wyoming (37\%) and mountain (39\%) subspecies). The shorter mean period of record for basin sagebrush may explain the higher recruitment rate and shorter recruitment intervals. However, big sagebrush recruitment is episodic, and our data suggest that for Wyoming sagebrush, statewide recruitment occurred in only 33 of the past 75 years.

Age-class frequency distributions of each stand and regional stand combination were assessed for dispersion across each associated period of record. No stands or regional stand combinations fit the Poisson distribution $(\mathrm{P}<0.0001)$ and all variances were greater than the mean, indicating recruitment is not random, but clustered, aggregated, or contagious (Zar 1999) across a period of record. With the exception of 1 mountain sagebrush stand, all stands and all three regional stand combinations fit the negative binomial distribution. Means were different for each stand and stand combination so $k$-exponent values also differed for each goodness-of-fit test (Table 3).

Cohort or age-class negative binomial distribution patterns were characterized by a relatively large number of years with no recruitment, a moderate number of years with some recruitment, and relatively few years with relatively high recruitment. Graphs of actual frequency probabilities for a representative stand and regional stand combination are displayed in Fig. 1.

\section{Conclusion}

1.3 to 2.7 years for basin sagebrush; and 1.2 to 2.9 years for mountain sagebrush. Mean recruitment intervals were shorter for basin sagebrush (1.6 years) than for Wyoming (2.3 years) and mountain (2.2 years) sagebrush. Years with high ageclass frequencies occurred at irregular intervals. This supports the hypotheses by Went (1955) and West et al. (1979) that successful recruitment in arid and semiarid plant communities occurs in pulses, often with many years of no seedling survival between successful years. Shorter intervals reflect more frequent, favorable
We suggest that big sagebrush plants dominating much of the current vertical structure of plant communities in Wyoming are relatively young. However, mean stand ages of Wyoming sagebrush in northeast and central Wyoming are approximately 3 to 4 times older than the mean fire-free interval ( 8 years) for the area (Perryman and Laycock 2000). Fire suppression activities are often associated with woody plant invasion of northern mixed-grasslands (Kucera 1981, Fisher et al. 1987, Steinaur and Bragg 1987).

Irregular pulses of recruitment are char- 
acteristic of big sagebrush stands in Wyoming. These results support hypotheses by Went (1955), West et al. (1979), and Cawker (1980), that recruitment in semi-arid regions occurs in pulses consistent with favorable climate. Other factors such as fire, insect outbreaks, herbivory, and understory composition may also affect demography patterns. However, without favorable weather, recruitment pulses may not occur.

Age-class frequency of big sagebrush stands approximate the negative binomial distribution. Characteristically, there are a large number of years of no recruitment, an intermediate number of years with some recruitment, and a few years of high recruitment. Recruitment intervals are longer for Wyoming and mountain sagebrush than for basin sagebrush. We believe these results reflect general trends of demography in other big sagebrush communities in Wyoming. Our large sample size (approximately 2200 individual plants) and regional consistency of results support our conclusion.

This study describes age-class frequency distributions and pulse recruitment phenomena of big sagebrush in Wyoming. However, future research must address mortality, survivorship curves, and the identification of climatic controls responsible for recruitment pulses of big sagebrush to fully understand the demography of this species.

\section{Literature Cited}

Barbour, M.G. 1969. Age and space distribution of the desert shrub Larrea divaricata. Ecol. 50:679-685.

Beetle, A. A. 1960. A study of sagebrush, the section Tridentatae of Artemisia. Wyo. Agr. Exp. Sta. Bull. No. 368, Laramie, Wyo.

Beetle, A. A. and K. L. Johnson. 1982. Sagebrush in Wyoming. University of Wyo. Agr. Exp. Sta., Laramie, Wyo.

Blaisdell, J.P. 1953. Ecological effects of planned burning of sagebrush-grass range on the Upper Snake River Plains. U.S. Dept. of Agr. Tech. Rep. No. 1075.

Bonham, C.D., T.R. Cottrell, and J.F. Mitchell. 1991. Inferences for life history strategies of Artemisia tridentata subspecies. J. of Veg. Sci. 2:339-344

Cawker, K.B. 1980. Evidence of climatic control from population age structure of Artemisia tridentata Nutt. in southern British Columbia. J. of Biogeogr. 7:237-248.

Chew, R.M. and A.E. Chew. 1965. The primary productivity of a desert shrub (Larrea tridentata) community. Ecol. Monogr., 35:355-375.

Diettert, R.A. 1938. The morphology of Artemisia tridentata Nutt. Lloydata, 1:3-74.

Ferguson, C. W. 1964. Annual rings in big sagebrush. Papers of the Laboratory of Tree-Ring Research No. 1. The University of Arizona Press, Tucson, A.riz

Fisher, R.F., J.J. Jenkins, and W.F. Fisher. 1987. Fire and the prairie-forest mosaic of Devil's Tower National Monument. Amer. Mid. Nat., 117:250-257.

Kucera, C.L. 1981. Grasslands and fire. In: Fire Regimes and Ecosystem Properties. USDA For. Serv. Gen. Tech. Rep. WO-26, 594p.
Ludwig, J.A. and J.F. Reynolds. 1988. Statistical Ecology: A Primer on Methods and Computing. John Wiley \& Sons, New York.

Moss, E.H. 1940. Interxylary cork in Artemisia with reference to its taxonomic significance. Amer J. Bot., 27:762-768.

Noy-Meir, I. 1973. Desert ecosystems: environment and producers. Annual Review of Ecology and Systematics, 4:25-51.

Perryman, B.L. and W.A. Laycock 2000. Fire history of the Rochelle Hills area of Thunder Basin National Grasslands. J. Range Manage.

Perryman, B.L. and R.A. Olson. 2000. Age-stem diameter relationships of big sagebrush and their management implications. J. Range. Manage.

Roughton, R.D. 1972. Shrub age structures on a mule deer winter range in Colorado. Ecol. 53:615-625.

Saville, D.J. 1990. Multiple comparison procedures: The practical solution. Amer. Statist. 44:174-180.

Steinauer, E.M. and T.B. Bragg. 1987. Ponderosa pine (Pinus ponderosa) invasion of Nebraska Sandhills prairie. Amer. Mid. Nat. 118:358-365

Vale, T.R. 1974. Sagebrush conversion projects: An element of contemporary environmental change in the western United States. Biol. Conserv., 6:274-284.

Went, R.W. 1955. The ecology of desert plants. Sci. Amer. 192:68-75.

West, N.E. 1978. Basic synecological relationships of sagebrush dominated lands in the Great Basin and Colorado plateau. In: The sagebrush ecosystem, A symposium, Logan, Ut, College of Natural Resources, Utah State Univ., Logan,Ut.

West, N.E., K.H. Rea, and R.O. Harniss. 1979. Plant demographic studies in sagebrush-grass communities of southeastern Idaho. Ecol. 60:376-388.

Zar, J.H. 1999. Biostatistical Analysis, 4th Ed. Prentice Hall, Upper Saddle River, New Jersey. 